\title{
THE SIGNIFICANCE OF PHILOSOPHY OF SCIENCE FOR HUMANITY IN ISLAMIC PERSPECTIVE
}

\author{
Zaprulkhan \\ STAIN Syaikh Abdurrahman Siddik, Bangka Belitung \\ e-mail: zaprulkhan_zahra@yahoo.com
}

\begin{abstract}
In Islamic perspective, researching universe is not only investigate the universe materially but also what is behind the universe itself. So, the universe was not viewed autonomously. This paper tried to elaborate significance of philosophy of science for humanity in Islamic perspective by using three fundamental structures of knowledge, namely ontology, epistemology, and axiology. Both Islam and science have to put humanity as center for research. The paradigm of Islamic science opens up an integral-holistic thought, and can not be separated from axiological meaning, that the purposes toward the enlightenment, progress, welfare, safety, and happiness for the whole human being in this world. So, Islam and science could give the most important roles to human's welfare and safety.

Dalam perspektif Islam, meneliti alam semesta tidaklah hanya mengkaji alam dari aspek materialnya, melainkan juga aspek spiritual di balik yang nyata sehingga alam semesta tidak dikaji secara berdiri sendiri. Tulisan ini mencoba mengelaborasi tentang signifikansi filsafat sains untuk kemanusiaan dari perspektif Islam dengan menggunakan tiga unsur pokok pengetahuan: ontologi, epistemologi dan aksiologi. Hasil kajian menunjukkan bahwa Islam dan sains sama-sama menjadikan nilai kemanusiaan sebagai objek penelitian. Paradigma ilmu pengetahuan Islam itu membuka cakrawala berpikir yang menyeluruh dan terintegrasi, dan tidak dapat dipisahkan dari makna aksiologinya yang bertujuan untuk pencerahan, perkembangan, kesejahteraan, keselamatan, dan kebahagiaan bagi seluruh umat manusia di dunia. Oleh karena itu, Islam dan ilmu pengetahuan memberikan peran yang sangat penting bagi kesejahteraan dan keselamatan manusia.
\end{abstract}

Keywords: Islamic perspective, humanity, philosophy of science, integral-holistic thought 


\section{A. Pendahuluan}

Osman Bakar salah seorang cendekiawan Muslim pakar filsafat sains Islam menegaskan nilai sakralnya alam semesta sebagaimana sakralnya Allah yang menciptakannya. Dia menulis:

"In Islam, the sacred in the ultimate sense is none other than God. The sacred (al-Quddūs) is one of the 99 Divine Names. From the sacred flows everything that is sacred in character, like sacred books, sacred laws, sacred knowledge, sacred art dan sacred architecture. Nature itself is of course viewed within the various spiritual tradition as sacred." ${ }^{\prime \prime}$

Melalui pernyataan tersebut, Osman Bakar ingin menunjukkan bahwa secara ontologis, eksistensi segala sesuatu tidak bisa bersifat otonom dan terlepas dari pusat sakralitasnya. Segala sesuatu, bahkan alam semesta sebagai makhluk 'mati' pun, karena ia merupakan manifestasi dari Sang Pencipta yang Maha Sakral (al-Quddūs), maka dalam level tertentu alam semesta bersifat sakral pula. Paradigma ini berimplikasi ketika mengkaji fenomena alam semesta, perspektif kaum Muslim tidak berhenti pada eksistensi material semata tapi berupaya menembus eksistensi spiritual, sumber sekaligus muara seluruh eksistensi.

Dengan demikian, paradigma saintifik Islam bersifat integral-holistik yakni tidak melakukan dikotomi secara ketat antara wilayah material dan spiritual, antara dimensi profan dan sakral, antara aspek bumi dan langit, melainkan saling berhubungan satu sama lain di bawah prinsip tawhìd. Dalam perspektif Muhammad al-Ghazali, paradigma integral-holistik sebenarnya terdapat dalam wacana al-Qur'an itu sendiri. Kapan pun al-Qur'an berbicara tentang alam semesta dalam segala aspeknya, maka tidak pernah dilepaskan dari Sang Penciptanya. $^{2}$

Dalam konteks ini pula, kajian filosofis sains dalam Islam tidak bisa dilepaskan dari makna aksiologisnya, yakni harus membawa implikasi praktis bagi kemajuan, kesejahteraan, keselamatan, dan kebahagiaan bagi umat manusia pada masa kini maupun masa depan. Karena itu, tulisan ini akan mendiskusikan signifikansi filsafat sains untuk kemanusiaan dalam perspektif Islam

\footnotetext{
1Zainal Abidin Bagir (ed.), Science and Religion, (Australia: ATF Press, 2005), h. 105.

${ }^{2}$ Lihat dalam Syaikh Muhammad al-Ghazali, Berdialog dengan al-Qur'an, terj. Masykur Hakim dan Ubaidillah (Bandung: Mizan, 1997). Harun Yahya, Pustaka Sains Populer Islami, terj. Catur Sriherwanto, (Bandung: Sygma Publishing, 2011).
} 
dengan menggunakan tiga unsur struktur fundamental filsafat ilmu yaitu ontologis, epistemologis, dan aksiologis. Ketiga struktur fundamental filsafat ilmu tersebut akan disoroti dari perspektif Islam dalam perbincangan filsafat sains. Tulisan ini diakhiri dengan sebuah konklusi berupa imbauan untuk menumbuhkembangkan semangat kajian filosofis saintifik kepada umat Islam kontemporer demi kesejahteraan dan kebahagiaan umat manusia.

\section{B. Ontologi Filsafat Sains}

Secara sederhana, ontologi merupakan cabang filsafat yang melukiskan hakikat keberadaan atau eksistensi sesuatu. ${ }^{3}$ Ontologi berupaya mencari struktur dasar dalam sebuah eksistensi atau objek yang dijelajahinya. ${ }^{4}$ Pertanyaan yang berhubungan dengan ontologi adalah apa hakikat eksistensi atau keberadaan itu? ${ }^{5}$ Dalam konteks sains, dimensi ontologi sains adalah alam semesta dengan segala perkakasnya. Dalam perspektif Mehdi Golshani, dalam al-Qur'an terdapat lebih dari tujuh ratus lima puluh ayat yang merujuk kepada fenomena alam semesta. ${ }^{6}$ Sedangkan dalam pengamatan Agus Purwanto, dalam al-Qur'an ternyata terdapat sekitar 1108 (seribu seratus delapan) ayat yang membicarakan tentang alam semesta dengan segala dimensinya. ${ }^{7}$

Dalam beragam ayat-Nya, Allah memerintahkan manusia untuk melakukan penjelajahan saintifik terhadap keragaman fenomena alam semesta baik yang berada di bumi maupun berada di ufuk cakrawala. Misalnya:

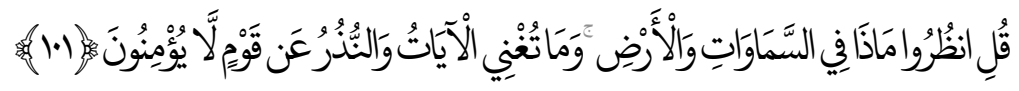

"Katakanlah (Nabi Muhammad): Perhatikanlah apa yang ada di langit dan di bumi. Tidaklah bermanfaat ayat-ayat (bukti-bukti kekuasaan Allah SWT) dan peringatan-peringatan bagi kaum yang tidak beriman."

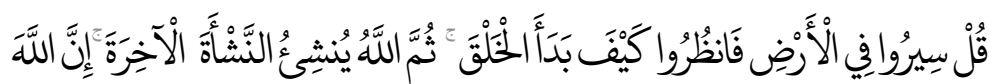

\footnotetext{
3Lorens Bagus, Kamus Filsafat, (Jakarta: Gramedia Pustaka Utama, 2002), h. 746-747.

${ }^{4}$ Lois O. Kattsoft, Pengantar Filsafat, (Yogyakarta: Tiara Wacana, 2004), h. 185-188.

${ }^{5}$ Stephen Palmquis, Pohon Filsafat, (Yogyakarta: Pusyaka Pelajar, 2007), h. 6; Jujun S. Suriasumantri, Filsafat Ilmu Sebuah Pengantar Populer, (Jakarta: Pustaka Sinar Harapan, 1996), h.33-35.

${ }^{6}$ Mehdi Golshani, Filsafat Sains Menurutal-Qur'an, terj. Agus Effendi, (Bandung: Mizan, 1989), h. 78.

${ }^{7}$ Agus Purwanto, Ayat-ayat Semesta, (Bandung: Mizan, 2009), h. 29. h. 220 .

${ }^{8}$ QS. Yunus [10]: 101, M. Quraish Shihab, al-Qur'an dan Maknanya, (Tangerang: Lentera hati, 2010),
} 


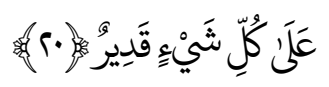

"Katakanlah (Nabi Muhammad): Berjalanlah di atas bumi, lalu perhatikanlah bagaimana Allah memulai penciptaan (semua makhluk), kemudian Allah menjadikannya di kali lain (yakni setelah penciptaan yang pertama itu). Sesungguhnya Allah Mahakuasa atas segala sesuatu."

Ayat-ayat tersebut dengan jelas memerintahkan manusia untuk memperhatikan, mengamati, dan meneliti secara saintifik seluruh fenomena yang ada pada wajah alam semesta. Jika bumi (ard]) merupakan representasi seluruh fakta kehidupan yang berada di atas kehidupan bumi yang meliputi manusia, hewan, tumbuh-tumbuhan dengan seluruh fenomena yang menyertainya, maka langit (samāwāt) sebagai representasi semua fenomena di luar bumi (langit) yang mencakup matahari, rembulan, bintang-gemintang dengan segala planet-planet lain yang mengiringinya. Dengan perintah tersebut, manusia sangat memungkinkan mampu mengeksplorasi dan menyingkap rahasia hukum-hukum kehidupan bumi sekaligus alam semesta secara saintifik. Sebab tidak mungkin Allah telah memerintahkan hamba-Nya untuk menelaah alam semesta, kalau kita sebagai hamba-Nya tidak mampu mengungkap misterinya secara ilmiah.

Namun dalam perspektif Islam, satu hal yang sangat prinsipil dalam mengkaji alam semesta beserta isinya adalah kesadaran kita bahwa alam semesta itu merupakan tanda-tanda (āyāt) dari Sang Pencipta. Dalam tilikan alQur'an, alam semesta tidak berdiri sendiri, melainkan sebagai tanda sekaligus simbol tentang makna-makna yang berada di baliknya. Berikut beberapa ayat al-Qur'an yang melukiskan bahwa alam semesta sebagai tanda-tanda (āyāt) bagi orang-orang yang berpikir:

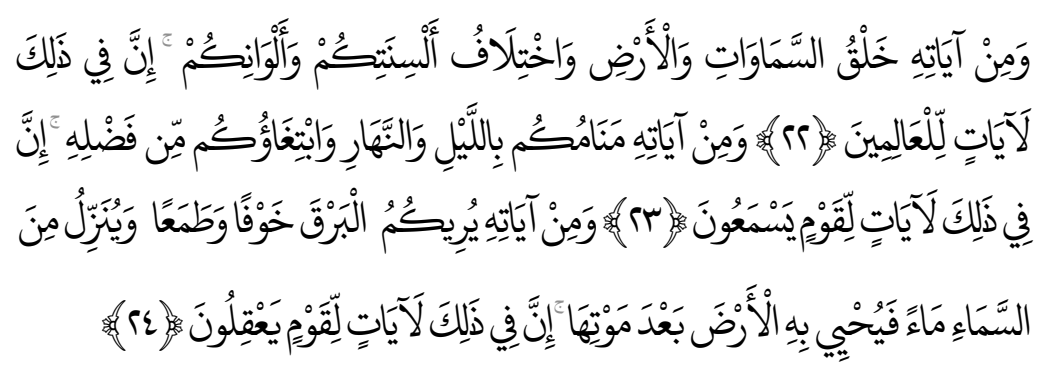

${ }^{9}$ QS. al-'Ankabut: [29]: 20, M. Quraish Shihab, al-Qur'an dan Maknanya, h. 398. 
"Dan di antara tanda-tanda (kekuasaan)-Nya adalah penciptaan langit dan bumi serta perbedaan lidah (bahasa dan dialek) kamu dan warna kulit kamu. Sesungguhnya pada yang demikian itu benar-benar (terdapat) bukti-bukti bagi orang yang dalam pengetahuannya". "Dan di antara tanda-tanda (kekuasaan)-Nya, Dia memperlihatkan kepada kamu kilat (untuk menimbulkan) ketakutan dan harapan (bagi turunya hujan), dan Dia menurunkan air dari langit, lalu denganya Dia menghidupkan (menyuburkan bumi sesudah mati/kering-nya). Sesungguhnya pada yang demikian itu benar-benar terdapat bukti-bukti bagi kaum yang berakal (yakni yang memikirkan dan merenungkannya)".10

Dengan berpijak pada prinsip-prinsip Qurani tersebut, menurut Osman Bakar, para ilmuwan Muslim era klasik telah memandang alam semesta sebagai simbol. Dalam paradigma tradisional Islam, simbol merupakan "refleksi" pada tingkat eksistensi yang lebih rendah, dari sebuah realitas yang datang dari status ontologis yang lebih tinggi. Alam yang lebih tinggi yang disimbolkan oleh simbol-simbol alamiah adalah alam spiritual. Sebagai contoh, matahari menyimbolkan Akal Ilahi; ruang angkasa yang luas menyimbolkan Keserbamungkinan Ilahi dan juga Kekekalan Ilahi; seekor burung menyimbolkan jiwa; sebatang pohon menyimbolkan tingkat-tingkat wujūd; dan air menyimbolkan pengetahuan dan hujan menyimbolkan wahyu. Kita dapat menyebutkan sejumlah tidak tehingga contoh yang lain. ${ }^{11}$

Dalam perspektif Osman Bakar, ada pertalian batin antara simbol dan yang disimbolkan. Pertalian ini bersifat metafisik, bukan fisik. Pengetahuan mengenai makna sebuah simbol atau tentang pertalian batin itu tidak dapat diperoleh melalui analisis logika atau matematika atau melalui investigasi empiris. Pengetahuan ini merupakan sains yang secara tradisional disebut sains tentang simbolisme, yang bersifat metafisik. Karenanya, sains simbolisme teramat penting dalam menyelidiki kesatuan antara sains dan pengetahuan spiritual. ${ }^{12}$

Sains simbolisme mengimplikasikan bahwa objek-objek alamiah tidak dipandang semata-mata sebagai fakta sebagaimana yang dilakukan oleh sains modern. Objek-objek atau fenomena alamiah yang diakui oleh kajian mate-

\footnotetext{
${ }^{10}$ QS. al-Rum [30]: 22 - 24, M. Quraish Shihab, al-Qur'an dan Maknanya, h. 406.

11Osman Bakar, Tauhid dan Sains, terj. Yuliani Liputo dan M.S. Nasrulloh, (Bandung: Pustaka Hidayah, 2008), h. 154-155. Kajian Osman Bakar tentang sains Islam juga sangat menarik dalam karya tersebut. Karenanya, karya ini juga akan menjadi sumber utama dalam tulisan ini.

120sman Bakar, Tauhid dan Sains, h. 155.
} 
matis dan empiris juga dipandang sebagai simbol-simbol. Ini artinya realitas sebuah objek alamiah tidak dituntaskan oleh kandungan matematis dan ilmiah belaka. Pengetahuan simbolik tentang objek-objek alamiah bukan hanya mungkin, tetapi tidak kurang nyata dibanding pengetahuan ilmiah atau matematisnya. Para ilmuwan Muslim abad-abad yang lalu telah memperlihatkan bahwa pengetahuan simbolik dan ilmiah tentang alam tidak saling bertentangan atau terpisah.

Kenyataannya, pengetahuan simbolik tentang alam membantu untuk mengungkap signifikansi metailmiah atau metafisik dari fakta-fakta, teori-teori dan hukum-hukum ilmiah yang ditemukan melalui kajian empiris alam semesta. Dalam sejumlah kasus yang diketahui, pengetahuan simbolik itulah yang diilhami para ilmuwan Muslim untuk menambah wilayah-wilayah kajian ilmiah baru yang menggiring pada penemuan-penemuan orisinal di wilayah tersebut. Sebuah contoh yang baik adalah bagaimana metafisika abad ke-12 Suhrawadi tentang cahaya dan kosmologi yang didasarkan pada simbolisme cahaya yang membantu untuk menghadirkan aktivitas ilmiah yang hebat di bidang optik pada abad ke-13 Islam. Quthbuddin al-Syirazi dan muridnya Kamaluddin al-Farsi menghasilkan penemuan penting di bidang ini. ${ }^{13}$

Paradigma filsafat sains Islam ini secara ontologis berbeda dengan paradigma filsafat sains Barat. Dalam paradigma filsafat sains Barat, sebagian besar ilmuwan mereka masih menganggap bahwa objek ontologis sains merupakan alam semesta yang bersifat independen dan tidak ada hubungan dengan sesuatu apa pun (apa lagi bersifat spiritual) di luar fenomena semesta. Objek ontologis sains adalah alam semesta yang bersifat empiris dan bisa diobservasi oleh indra.

Menurut Mulyadhi Kartanegara, alasan yang biasanya di kemukakan oleh sains modern untuk membatasi objek-objek ilmu ini hanya pada bidang fisikempiris adalah karena objek-objek ini sajalah yang bisa diteliti secara objektif dan karena itu bisa diverifikasi kebenarannya. Sedangkan objek-objek non-fisik tidak bisa dicerap secara objektif sehingga akan sulit untuk diverifikasi atau

${ }^{13}$ Osman Bakar, Tauhid dan Sains, h. 155-156. Tentang kontribusi para ilmuwan Muslim ini, bisa dilihat dalam Husein Heriyanto, Menggali Nalar Saintifik Peradaban Islam, (Bandung: Mizan, 2011), h. 178-179; Mehdi Nakosteen, Kontribusi Islam atas Dunia Intelektual Barat, terj. Joko S. Kahhar dan Supriyanto Abdullah, (Surabaya: Risalah Gusti, 2003), h. 245. 
klarifikasi karena subjektivitas yang terlibat di dalamnya. Dengan demikian, objek-objek tersebut tidak bisa diinvestigasi secara ilmiah. ${ }^{14}$

Sedangkan dalam perspektif Syed Muhammad Naquib al-Attas, sains modern memang dibangun dari pandangan dunia sekularistik dan materialistik, yakni pandangan yang bertumpu pada realitas fisik material dan mengingkari realitas nonfisik-immaterial (realitas metafisik). Realitas fisik tersebut bekerja secara alamiah, mandiri terlepas dari agen apa pun. Karena itu tidak ada tempat bagi Tuhan dan para pembantunya yang terdiri dari para malaikat yang dalam kosmologi Islam tradisional dipercaya sebagai agen penting dalam mekanisme kerja alam.

Secara umum pandangan sekuler ini membuang segala unsur ilāhiyyah atau metafisik bagi alam fisik. Eksistensi yang diakui keberadaanya hanyalah alam țabi'i yang dapat dicermati secara empirik. Semuanya yang dapat diobservasi dianggap sebagai bahan-bahan yang selanjutnya diolah oleh daya rasional. Rasionalisme, empirisme, dan sekularisme menjadi paham yang mendasari sains Barat modern. Dalam bahasa yang lebih tegas, al-Attas menyatakan bahwa sains Barat hanya berhubungan dengan 'fenomena' sebagai satu-satunya realitas. ${ }^{15}$

Bagi al-Attas, meskipun realitas fisik diakui eksistensinya, namun realitas fisik tidak independen dan mengatur dirinya sendiri seperti pandangan umum paham sekuler. Eksistensi realitas fisik tergantung pada realitas non fisik. Ia adalah lambang yang kehadirannya tergantung pada makna yang ada di baliknya, sebagaimana kata, sekalipun memiliki eksistensi sendiri, ia hadir untuk menunjukkan makna yang dikandungnya. Ia tidak berdiri sendiri. Karena itu, alam fisik juga disebut ayat dalam alam semesta yang merupakan sebuah "Kitab". Dengan posisinya ini, menjadikan dunia fisik meterial sebagai objek sains harus selalu dikaitkan dengan realitas di baliknya. Artinya, kajian tentang dunia fisik tidak bisa hanya berhenti pada objek tersebut. Kajian saintifik harus menyingkap makna berupa realitas metafisik yang ada di baliknya. Objek fisik adalah objek instrumental untuk mengantar pada pengetahuan metafisik.

${ }^{14}$ Mulyadhi Kartanegara, Integrasi Ilmu, (Jakarta: UIN Jakarta Press, 2005), h. 59.

15Dikutip dari Ach. Maimun Syamsuddin, Agama dan Sains, (Yogyakarta: IRCiSoD, 2012), h. 229231. Karya Ach. Maimun ini mengkomparasikan pemikiran sains Islam antara dua pemikir Islam kontemporer yakni Syed Naquib al-Attas dan Mehdi Golshani dengan kajian mendalam dan dinarasikan dengan bahasa akademikyang elegan sekali. 
Jika hanya berkutat pada objek fisik tanpa mengaitkannya dengan realitas metafisik, berarti pengetahuan itu tidak mencapai tujuan utamanya, sebagaimana seseorang hanya mengkaji kata dan berbagai kaitannya dengan kata yang lain tanpa beranjak lebih lanjut untuk menyingkap makna yang dikandungnya. Padahal makna itu merupakan tujuan kehadiran kata. Dalam analogi yang lain al-Attas menyebut orang yang hanya mengkaji alam fisik tanpa mengaitkannya dengan realitas metafisik seperti orang yang terpesona dengan petunjuk arah atau rambu dalam suatu jalan dan tidak menangkap maknanya untuk melanjutkan perjalanan. Dengan demikian, pengetahuannya tidak mencapai tujuan hakiki. Bahkan jika mengklaim realitas fisik sebagai satu-satunya realitas dan mengingkari realitas metafisik, berarti ia telah tersesat dan tidak mencapai kebenaran. ${ }^{16}$ Dalam perspektif Ach. Maimun Syamsuddin, catatan kritis al-Attas terhadap sains Barat bernuansa teologis sehingga menegaskan signifikansi penetrasi agama ke wilayah sains. ${ }^{17}$

Sedangkan menurut Osman Bakar, beragam wawasan sains tentang semesta merupakan sains yang bersifat partikular sehingga harus dikaitkan kepada konsep tawhīd sebagai sains universal. Sains-sains partikular dapat dipadukan secara konseptual ke dalam sains metafisika tentang tawhïd karena Prinsip Ilahi merupakan sumber metafisik bagi keanekaragaman dunia yang menjadi pokok pembahasan sains-sains partikular itu. ${ }^{18}$ Namun dalam perspektif Osman Bakar, "perangkat konseptual" yang dibutuhkan untuk integrasi itu perlu diturunkan dari kosmologi. Kosmologi mampu untuk menjadi "alat integrasi konseptual" karena tujuannya adalah "untuk mengadakan sebuah sains yang memperlihatkan kesalingterkaitan segala sesuatu dan hubungan tingkat-tingkat hierarki kosmik satu sama lain dan akhirnya dengan Prinsip Tertinggi. Dengan demikian ia menjadi sebuah pengetahuan yang memungkinkan terjadinya integrasi keanekaragaman ke dalam keterpaduan".19

Berhubungan dengan kosmologi ini, ada tiga tingkat eksistensi kosmik yang fundamental, yaitu spiritual, subtil, dan fisik. Pembagian kosmos ini merupakan pembagian yang kualitatif atau "vertikal" karena ia merujuk pada tingkat kualitas yang berbeda-beda. Kosmologi memberi kita pengetahuan

\footnotetext{
${ }^{16}$ Ach. Maimun Syamsuddin, Agama dan Sains, h. 237-238.

${ }^{17}$ Ach. Maimun Syamsuddin, Agama dan Sains, , h. 234.

${ }^{18}$ Osman Bakar, Tauhid dan Sains, h. 163.

${ }^{19}$ Osman Bakar, Tauhid dan Sains, h. 163-174.
} 
tentang keterkaitan ketiga alam ini. Alam spiritual merupakan dasar bagi alam subtil dan alam subtil merupakan dasar bagi alam fisik. Oleh karena itu, kosmologi menghendaki agar dunia fisik diperlakukan bukan sebagai wilayah otonom yang terputus dari tingkat realitas yang lebih tinggi. ${ }^{20}$

Dengan demikian, secara ontologis, alam semesta mesti kita baca secara simbolos untuk menguak makna yang tersimpan di baliknya dan untuk menemukan Sang Pencipta muara bergantungnya alam semesta. Paradigma tauhidik dalam sains Islam yakni bahwa seluruh dimensi objek (ontologis) dalam alam semesta merupakan refleksi dari Tuhan yang Tuggal sehingga harus dibaca dalam perspektif tauhidik memang telah menyatu dalam sains Islam klasik. ${ }^{21}$

\section{Epistemologi Filsafat Sains Islam}

Secara etimologis, epistemologi berasal dari bahasa Yunani episteme yang berarti pengetahuan atau ilmu pengetahuan dan logos yang berarti pengetahuan atau informasi. ${ }^{22}$ Epistemologi atau filsafat pengetahuan pada dasarnya juga merupakan suatu upaya rasional untuk menimbang dan menentukan nilai kognitif pengalaman manusia dalam interaksinya dengan diri, lingkungan sosial, alam sekitarnya. Sebagai kajian filosofis yang membuat telaah kritis dan analitis tentang dasar-dasar teoritis pengetahuan, epistemologi kadang juga disebut teori pengetahuan (theory of knowledge). ${ }^{23}$ Secara general, epistemologi juga memperbincangkan sumber pengetahuan dan cara mendapatkan pengetahuan. Pertanyaan sederhana yang berhubungan dengan epistemologi adalah bagaimana caranya mendapatkan pengetahuan tersebut? ${ }^{24}$

Dalam konteks filsafat sains, epistemologi yang akan kita diskusikan hanya berhubungan dengan sumber dan cara mendapatkan pengetahuan saintifik. Dalam perspektif Islam, secara global sumber saluran yang digunakan untuk memahami alam adalah: Indra-indra eksternal (dengan indra ini pengamatan dan ekperimen dapat dilakukan), intelek yang tidak terkotori oleh sifat-sifat

\footnotetext{
${ }^{20}$ Osman Bakar, Tauhid dan Sains, h. 164-167.

${ }^{21}$ Contoh-contoh yang sangat demonstratif mengenai hal ini lihat dalam Seyyes Hossein Nasr, Science and Civilization in Islam, (New York: A Plume Book, 1970).

${ }^{22}$ Lorens Bagus, Kamus Filsafat, h. 212.

23Jujun S. Suriasumantri, Filsafat Ilmu Sebuah Pengantar Populer, (Jakarta: Pustaka Sinar Harapan, 1996), h. 18.

${ }^{24}$ Jujun S. Suriasumantri, Filsafat Ilmu Sebuah Pengantar Populer, h. 35.
} 
buruk (yang menguasai kehendak-kehendak dan khayalan-khayalan, dan bebas dari peniruan buta), serta wahyu dan inspirasi. 25

Pertama, indra-indra eksternal melalui pengamatan atau observasi. Dalam al-Qur'an ada beberapa ayat yang memerintahkan manusia agar menggunakan panca indranya dalam mencari kebenaran di alam semesta. Misalnya:

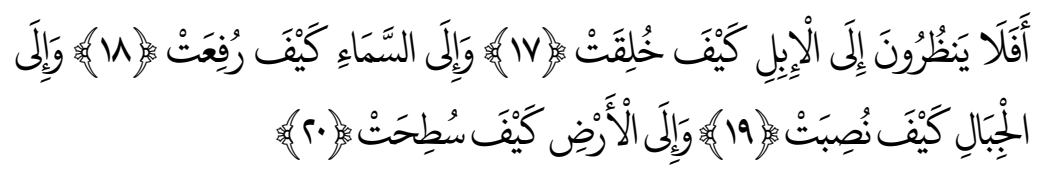

"Maka tidakkah mereka memperhatikan (bukti kuasa Allah SWT di alam semesta, antara lain) kepada unta bagaimana ia diciptakan? Dan (apakah mereka tidak merenungkan) langit, bagaimana ia ditinggikan? Dan gununggunung bagaimana ia ditegakkan? Dan bumi bagaimana ia dihamparkan?"26

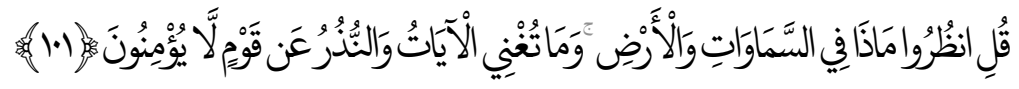

"Katakanlah (Nabi Muhammad): Perhatikanlah apa yang ada di langit dan di bumi. Tidaklah bermanfaat ayat-ayat (bukti-bukti kekuasaan Allah SWT) dan peringatan-peringatan bagi kaum yang tidak beriman."27

Ayat-ayat di atas mengindikasikan bahwa penggunaan kapasitas indra melalui jalan observasi sangat dianjurkan oleh al-Qur'an. Ketika al-Qur'an memerintahkan manusia untuk menggunakan indra dalam pengamatan saintifik terhadap alam semesta, itu berarti indra bukan hanya mampu menyingkap sebagian makna pada wajah alam semesta, tetapi juga indra mempunyai signifikansi tersendiri. Lalu bagaimana operasional indra dalam membaca fakta empiris? Berikut ini argumentasi filosofis Mulyadhi Kartanegara.

Dalam perspektif Mulyadhi Kartanegara, berbeda dengan ahli neurologi modern, menurut para filosof Muslim, indra merupakan kecakapan (daya) jiwa, yang dimiliki oleh setiap hewan (termasuk manusia), dan bukan hanya sekedar kecakapan fisik seperti yang dibayangkan banyak ilmuwan modern. Jadi, bersama dengan gerak (harakah), dan indra (sensasi) merupakan kecakapan jiwa manusia. Sebagai kecakapan jiwa, indra-indra manusia ini bekerja dengan

\footnotetext{
${ }^{25}$ Mehdi Golshani, Filsafat Sains Menurut al-Qur'an, h. 84; Lihat juga dalam Mehdi Gulshani, Melacak Jejak Tuhan dalam Sains, terj. Ahsin Muhammad (Bandung: Mizan, 2004), h. 28.

${ }^{26}$ QS. al-Ghasyiyah [88[:17-20, M. Quraish Shihab, al-Qur'an dan Maknanya, h. 592.

${ }^{27}$ QS. Yunus [10]: 101, M. Quraish Shihab, al-Qur'an dan Maknanya, h. 220.
} 
sangat menakjubkan. Mata, misalnya, dengan sel-sel saraf yang berhubungan dengan cahaya, dapat mencerap bukan hanya bentuk benda-benda fisik yang diamatinya, melainkan juga warna mereka. Gelombang cahaya yang masuk ke retina ternyata mampu diterjemahkan oleh mata sebagai warna dan bentuk benda-benda. Dengan demikian, objek-objek fisik yang dapat ditangkapnya dengan bantuan cahaya juga bisa menimbulkan keindahan yang luar biasa bagi siapa saja yang mengamatinya. Sinar lembayung yang memesona, seperti yang dapat kita amati lewat jendela kaca rumah saya sekarang, dapat menimbulkan keindahan yang luar biasa serta sensasi yang menyenangkan pada diri saya.

Demikian juga sensasi yang dilakukan oleh telinga kita, sesungguhnya sangat mengagumkan. Gelombang suara yang masuk atau ditangkap oleh telinga kita diterjemahkan, setelah melalui proses yang sangat rumit yang melibatkan alat-alat pendengaran, seperti gendang suara dan siput telinga, sebagai suara yang beraneka ragam. Suara yang kita terima sebenarnya adalah berita atau informasi tentang sebuah benda, bukan dari sudut bentuknya, yang bisa ditangkap oleh indra mata, melainkan dari sudut lain, seperti harmoni dalam kasus musik, kedahsyatan atau kekuatannya seperti dalam kasus halilintar; indra pendengaran juga sangat penting terutama sebagai media audio, melalui apa kita bisa menyimak kuliah, ceramah, pidato, atau sebagai alat komunikasi dan berdialog yang dilakukan dalam kehidupan kita sehari-hari. Dengan bantuan indra pendengaran ini, manusia dapat menangkap ide-ide yang disampaikan dalam bentuk suara.

Demikian juga indra penciuman dapat memberi informasi yang tidak dapat dicerap oleh penglihatan maupun pendengaran untuk mengidentifikasi hal-hal yang tersembunyi, seperti wangi-wangian, bunga atau parfum, atau bau busuk, seperti makanan yang basi atau bangkai tikus yang tersembunyi, atau bau sangit yang datang dari benda-benda terbakar. Bahkan, bagi hewan tertentu, seperti anjing dan kucing, alat penciuman ini merupakan sarana yang krusial untuk mencari makanan dan sebagainya. Demikian juga indra yang lain, seperti indra perasa dan indra peraba. Indra perasa yang terletak pada lidah juga merupakan alat tubuh yang sangat berguna untuk mendapatkan informasi tentang rasa dari sebuah benda, misalnya makanan dan minuman, sebab melalui indra inilah kita bisa mengetahui kalau benda tersebut pahit, manis, asam, asin, dan gurih. Kalau tidak ada panca indra ini, tidak bisa dibayangkan akan munculnya pabrik-pabrik makanan, seperti roti, bakso, kue-kue basah, kue-kue kering, bahkan juga beraneka ragam minuman. Segala macam rasa, 
baik yang terdapat dalam makanan buatan maupun buah-buahan tidak akan punya makna apa pun kalau kita sendiri tidak memiliki indra rasa tersebut. Dengan demikian, indra perasa bisa menjadi sumber informasi yang melimpah tentang rasa dari berbagai jenis makanan dan minuman.

Terakhir adalah indra peraba, yang menyebar di seluruh permukaan tubuh kita. Sebagaimana indra-indra lainnya, indra peraba ini juga amat berguna sebagai sumber pengetahuan manusia khususnya tentang benda-benda fisik dari sudut lembut atau kasarnya, dingin atau panasnya. Alat peraba, seperti tangan, sangat berguna untuk menilai apakah "kopi" ini terlalu dingin atau panas, bahan baju ini lembut atau kasar, dan sebagainya. Bahkan, dengan kepekaan yang dimiliki oleh jari-jari kita (khususnya ujungnya), seseorang bisa mengenali apakah kertas yang digengamnya itu uang atau sekedar kertas biasa. Bahkan, seorang yang buta pun, dengan tangannya, dapat membedakan nilai uang (kertas) antara yang satu dengan yang lainnya. Dengan demikian, ia dapat menjadi sumber informasi yang juga sangat mengagumkan. Singkat kata, pancaindra ini telah memungkinkan manusia untuk bisa mencerap berbagai dimensi dari sebuah benda yang diamatinya sehingga indra ini akan menjadi alat pengamat benda-benda fisik yang sangat canggih dan berguna sebagai sumber informasi. Demikian pentingnya mereka sehingga bagi para pendukung empirisme, indra-indra ini dipandang sebagai satu-satunya sumber pengetahuan yang dapat dipercaya dan diandalkan.

Dari uraian di atas, jelas bahwa indra-indra manusia mampu menggali beragam informasi dari benda-benda fisik yang diamatinya dengan cara yang sangat unik dan canggih. ${ }^{28}$ Dalam dunia modern, karena keterbatasanketerbatasan indra, para saintis menciptakan alat-alat bantu, seperti teleskop untuk benda-benda yang jauh, atau mikroskop untuk benda-benda yang terlalu kecil. Dengan demikian, pengamatan indra bisa menjangkau ke dalam yang tidak pernah terbayangkan oleh pikiran manusia. Misalnya bisa mengamati supernova (yaitu peristiwa kelahiran bintang-bintang) yang terjadi puluhan/ belasan miliar tahun yang lalu. Demikian juga dengan instrumen yang canggih, atom yang tidak bisa dilihat oleh mata telanjang ternyata masih bisa diamati bahkan dibagi ke dalam bagian-bagian yang lebih kecil lagi yang disebut hadron, seperti elektron, proton, neutron, dan quark.29

${ }^{28}$ Mulyadhi Kartanegara, Integrasi Ilmu, (Jakarta: UIN Jakarta Press, 2005), h. 101-105.

${ }^{29}$ Mulyadhi Kartanegara, Integrasi Ilmu, h. 100-101. 
Meskipun demikian, dalam tilikan ilmuwan Muslim, kapasitas indra-indra kita mempunyai banyak kelemahan sehingga membuat informasi mereka sering tidak bisa dipercaya. Misalnya mata, ia sering membuat banyak kekeliruan dalam pengamatannya. Bintang yang sebenarnya besar, ia laporkan kecil. Pensil yang lurus, ia laporkan bengkok ketika kita masukkan pensil tersebut ke dalam air. Dengan demikian, ternyata tidak semua benda dapat dilihat oleh mata karena mata kita hanya bisa menangkap, dan kemudian menerjemahkan gelombang cahaya dalam frekuensi tertentu, yaitu antara 400700 nanometer. Lebih atau kurang dari frekuensi tersebut, mata kita tidak bisa lagi melihat. Akibatnya, sinar kosmik, sinar gamma, sinar $\mathrm{x}$, inframerah, dan ultraviolet luput dari pengamatannya. Demikian juga telinga, dengan kemampuannya untuk bisa mencerap gelombang suara dengan frekuensi tertentu saja (20-20.000 kilohertz/detik), ternyata tidak mampu menangkap banyak suara, baik yang tergolong lebih rendah (infrasonik) ataupun lebih tinggi (ultrasonik). Tetapi, keterbatasannya yang paling nyata adalah ketidakmampuannya untuk mencerap entitas-entitas nonfisik ${ }^{30}$ Pada titik inilah, kelemahan-kelemahan indra kita mesti dilengkapi dengan saluran kedua, yaitu akal.

Kedua, fakultas akal. Dalam pengamatan Golshani, dalam kebanyakan ayat al-Qur'an, di manapun fenomena alam disebutkan, secara eksplisit ditunjukkan bahwa mempersepsi ayat-ayat Ilahi di dalam alam dan hubungannya terhadap Tuhan ada dalam jangkauan manusia yang memiliki intelek. Berikut ini adalah beberapa contoh ayat tersebut:

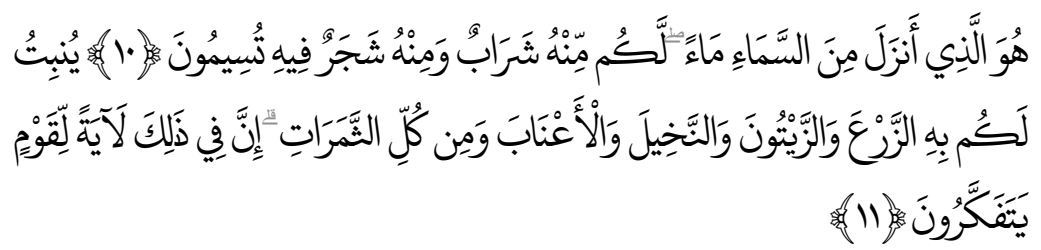

“Dia-lah Allah yang menurunkan air hujan dari langit untuk kamu, sebagiannya menjadi minuman dan sebagiannya (menyuburkan) tumbuhtumbuhan yang (pada tempat tumbuhnya) kamu menggembalakan ternakmu. Dia menumbuhkan bagi kamu dengan air hujan itu tanamtanaman: zaitun, korma, anggur, dan segala amcam buah-buahan. Se-

30Mulyadhi Kartanegara, Integrasi Ilmu, h. 106. 
sungguhnya pada yang demikian itu benar-benar ada tanda-tanda bagi kaum yang bertafakur." 31

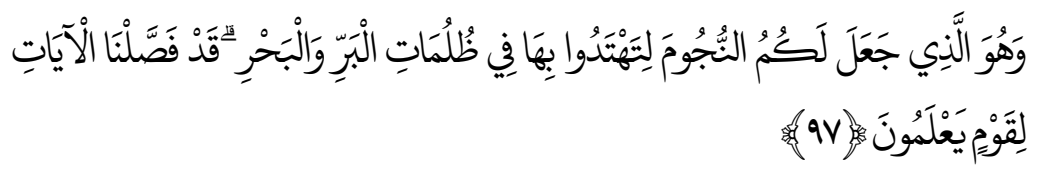

"Dan Dia-lah Allah yang menjadikan bintang-bintang bagimu agar kamu menjadikannya petunjuk dalam kegelapan di darat dan di laut. Sesungguhnya Kami telah Menjelaskan tanda-tanda kebesaran (Kami) kepada orangorang yang mengetahui." 32

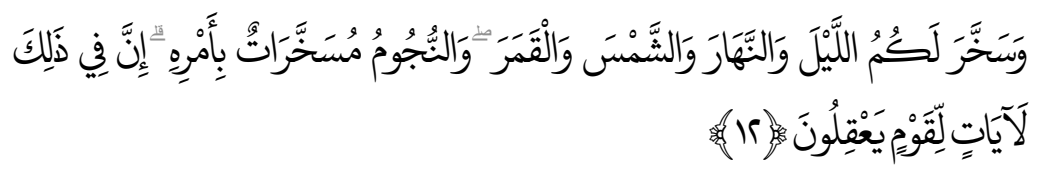

"Dan Dia menundukkan malam dan siang, matahari dan bulan untukmu. Dan binatang-binatang itu ditundukkan (untukmu) dengan perintah-Nya. Sesungguhnya pada yang demikian itu benar-benar ada tanda-tanda bagi kaum yang berakal." 33

Penggunaam kata-kata seperti tafakkur, ta'aqqul, dan tafaqquh dalam ayatayat tersebut di atas menunjukkan (dengan penekanan yang berbeda) bahwa untuk memahami alam, seseorang harus menggunakan inteleknya. ${ }^{34}$ Dalam konteks ini, meskipun observasi dan eksperimentasi tidak dapat dihindari untuk meraih informasi dari dunia eksternal, ia bukanlah alat-alat yang cukup. Bila kita hanya bersandar pada indra-indra eksternal, kita tidak akan mampu menafsirkan dunia fisik, dan menemukan hubungan di antara kejadiankejadian alam.

Pada kenyataannya, manusia tidak berbeda dengan binatang-binatang lainnya sejauh menyangkut indra-indra eksternal tersebut, bahkan dalam hal ini beberapa binatang lebih baik dari manusia. Apa yang membedakan manusia dari binatang adalah keahliannya yang tinggi dalam mengamati dunia dan menafsirkan kejadian-kejadian di dalamnya. Ini dikarenakan fakultas yang disebut fakultas rasional yang mampu menghubungkan tanda-tanda dan

${ }^{31}$ QS. al-Nahl [16]: 10-11.

${ }^{32} \mathrm{QS}$. al-An'am [6]: 97.

${ }^{33}$ QS. al-Nahl [16]: 12.

${ }^{34}$ Mehdi Gulshani, Filsafat Sains Menurutal-Qur'an, h. 86-87. 
simbol-simbol yang diraih lewat indra-indra, dan mampu menafsirkannya. Indra-indra memberi kita serangkaian tanda-tanda dan simbol-simbol yang tidak berkaitan dan intelek membuka hubungan-hubungan di antaranya. ${ }^{35}$

Bahkan dalam al-Qur'an ada sejumlah ayat yang menunjukkan bahwa bagi sebagian orang, indra mereka tidak berfungsi dengan baik ketika melihat tanda-tanda Tuhan pada wajah alam semesta. ${ }^{36}$ Misalnya:

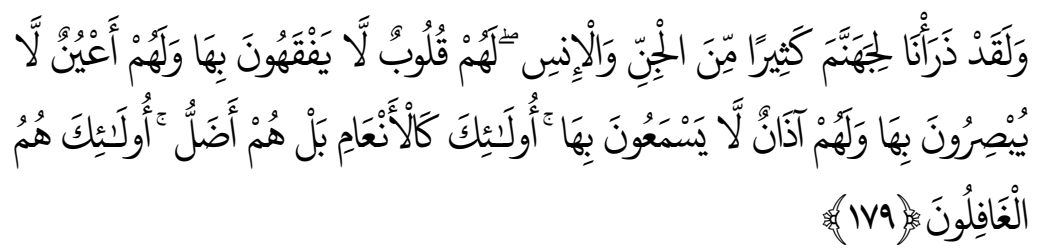

"Dan demi (keagungan dan kekuasaan Kami), sungguh Kami telah menciptakan untuk (isi neraka) Jahannam banyak dari jin dan manusia (karena kesesatan mereka); mereka mempunyai hati, tetapi tidak mereka gunakan memahami (ayat-ayat Allah) dan dia mempunyai mata (tetapi) tidak mereka gunakan melihat (tanda-tanda kekuasaan Allah) dan mereka mempunyai telinga (tetapi) tidak mereka gunakan untuk mendengar (petunjuk-petunjuk Allah). Mereka itu seperti binatang ternak, bahkan mereka lebih sesat. Mereka itulah orang-orang yang lalai." ${ }^{37}$

Ayat lainnya:

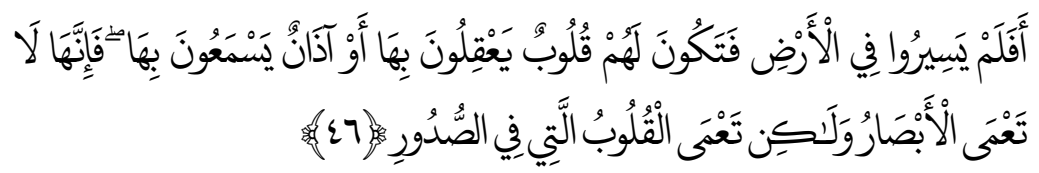

"Maka apakah mereka tidak berjalan di bumi, lalu mereka memiliki hati yang dengannya mereka dapat memahami atau mereka memiliki telinga yang dengannya mereka dapat mendengar, karena sesungguhnya bukanlah mata yang buta, tetapi yang buta (ialah) hati yang berada di dalam dada." ${ }^{38}$

Berpijak pada ayat-ayat tersebut, Golshani memberikan interpretasi bahwa mata, telinga, dan indra-indra eksternal lainnya adalah alat bagi akal; dan itu semua hanya bisa berfungsi dengan sempurna dan bermakna penuh jika berjalan melalui saluran intelek. Mata melihat, sedang akal menafsirkan hasil

35Mehdi Gulshani, Filsafat Sains Menurutal-Qur'an, h. 87-88.

36Mehdi Gulshani, Filsafat Sains Menurutal-Qur'an, h. 174.

${ }^{37}$ QS. al-A'raf [7]: 179.

${ }^{38}$ QS. al-Hajj [22]:46, M. Quraish Shihab, al-Qur'an dan Maknanya, h. 337. 
penglihatan dan menyatakan keputusan. Fungsi penglihatan dapat dianggap sempurna bila sejalan dengan wawasan, yaitu ketika sensori (yang berhubungan dengan panca indra) dilengkapi dengan intelek (suprasensori). ${ }^{39}$

Selain itu, menurut Mulyadhi Kartanegara, kelebihan yang paling istimewa pada akal terletak pada kecakapan atau kemampuannya untuk menangkap "kuiditas" atau "esensi" dari sesuatu yang diamati atau dipahami. Dengan kecakapan ini, akal manusia dapat mengetahui konsep universal dari sebuah objek yang diamatinya lewat indra yang bersifat abstrak dan tidak lagi berhubungan dengan data-data partikular. Ketika kita memahami "esensi" manusia, sebenarnya kita bukan lagi berbicara tentang manusia partikular $a$ atau $b$, melainkan berbicara tentang manusia dalam pengertian manusia yang universal -atau tentang sifat dasar kemanusiaan. Ketika berbicara tentang meja, kita bukan lagi berbicara tentang meja yang berbentuk segitiga, segiempat, segilima, atau berbentuk ati-ati, melainkan berbicara tentang hakikat atau kuiditas yang meliputi semua meja partikular atau tertentu. Inilah yang disebut oleh Aristoteles dengan "bentuk" (form/șürah). Dengan kemampuan akal menangkap esensi (māhiyyah) dari benda-benda yang diamatinya, manusia bisa menyimpan jutaan "makna" dan "pemahaman" tentang pelbagai objek ilmu yang bersifat abstrak sehingga tidak memerlukan ruang fisik yang luas di dalam pikiran kita. ${ }^{40}$

Sampai di sini, sudah cukupkah kita hanya mengandalkan indra dan akal sebagai sumber pengetahuan? Akal boleh memiliki kecakapan yang luar biasa, baik untuk menangkap objek-objek fisik maupun non-fisik, tetapi ia juga memiliki keterbatasan-keterbatasannya yang fundamental. Mengomentari kelebihan dan kekurangan akal, Ibn Khaldun mengatakan, "Sebagai timbangan emas dan perak, akal adalah sempurna; tapi masalahnya bisakah timbangan emas dipakai untuk menimbang gunung? Dengan demikian, akal betapapun sempurnanya sebagai sumber ilmu, tetap saja, menurut para pemikir Muslim, memiliki kekurangan-kekurangan yang fundamental karena masih banyak hal besar yang berada di luar jangkauan akal. Akal menjadi alat analisis dan sumber ilmu hanya pada sektor tertentu, tetapi bungkam pada sektor yang lainnya." ${ }^{41}$

\footnotetext{
${ }^{39}$ Mehdi Gulshani, Filsafat Sains Menurut al-Qur'an, h. 89.

40Mulyadhi Kartanegara, Pengantar Epistemologi Islam, (Bandung: Mizan, 2003), h. 25.

41Mulyadhi Kartanegara, Integrasi Ilmu, h. 110.
} 
Pada titik inilah, diperlukan sumber pengetahuan yang ketiga yaitu intuisi dan wahyu. Dalam perspektif Golshani, intuisi dan wahyu mempunyai peran signifikan untuk menyingkap fenomena alam semesta. ${ }^{42}$ Ada sejumlah ayat alQur'an mengenai isyarat tersebut:

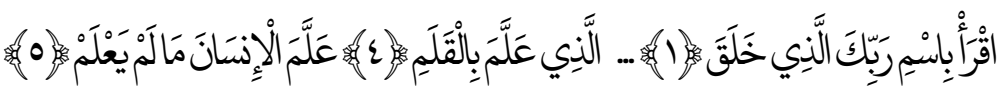

"Bacalah dengan nama Tuhanmu yang menciptakan..., yang mengajari (untuk menulis) dengan pena. Mengajari manusia, apa yang tidak diketahuinya." 43

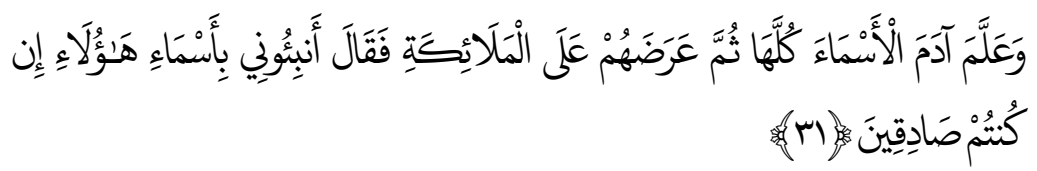

"Dan Dia mengajarkan kepada Adam nama-nama (benda-benda) seluruhnya, kemudian mengemukakannya kepada para Malaikat lalu berfirman: "Sebutkanlah kepada-Ku nama benda-benda itu jika kamu memang orang-orang yang benar!" 44

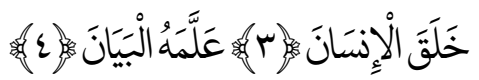

"Dia telah menciptakan manusia, mengajarinya bicara." 45

Sejumlah ayat al-Qur'an tersebut menunjukkan bahwa di samping saluransaluran pengamatan biasa, yaitu perenungan dan pengintelekan (intellection), ada cara yang lebih langsung dalam meraih pengetahuan akan realitas dunia lewat Sang Pemberi pengetahuan; tetapi cara ini bukanlah cara yang umum, dan hanya orang-orang yang beriman pilihan sajalah yang dapat melewatinya. ${ }^{46}$

Menurut Golshani, para filosof Muslim percaya bahwa manusia yang memiliki kemampuan untuk meraih ilmu langsung semacam itu adalah mereka yang dianugerahi dengan "fakultas kewalian" (quwwah qudsiyyah atau saintly faculty). Untuk menerangkan penalarannya, kita kembali ke belakang, dan

42Mehdi Gulshani, MelacakJejak Tuhan dalam Sains, h. 34-39.

${ }^{43}$ QS. al-'Alaq [96]: 1, 4-5.

${ }^{44}$ QS. al-Baqarah [2]: 31.

${ }^{45}$ QS. al-Rahman [55]: 3-4.

46Mehdi Gulshani, Filsafat Sains Menurutal-Qur'an, h. 95-96. 
melihat bahwa satu di antara saluran-saluran pengetahuan itu adalah berpikir (logis). Dalam berpikir, pikiran mengalami dua fase gerakan, dan bolak-balik antara yang diketahui dan yang tidak diketahui. Didalam berpikir, seseorang mencari sebuah pernyataan pertengahan yang sama dalam kedua proposisi yang diberikan; dengan bantuan ini ia bisa berharap untuk memahami apa yang tidak diketahui. Secara umum, menemukan pernyataan pertengahan memerlukan premis-premis tertentu. Bahkan dalam kejadian-kejadian khusus tertentu, sebagian orang bisa mencapai pernyataan pertengahan dan kesimpulannya tanpa membentuk silogisme dalam pikiran mereka. Bakat mental yang membawa seseorang kepada tujuan tanpa mengikuti langkah-langkah logis ini disebut intuisi, dan dalam bentuknya yang tertinggi disebut "fakultas kewalian". Seorang yang memiliki pemberian ini dapat mengetahui banyak realitas tanpa menggunakan indra fakultas-fakultas dan indra rasionalnya. ${ }^{47}$

Menurut laporan Mulyadhi Kartanegara, Ibn Arabi dalam karyanya yang berjudul Risālah al-Anwār fí mā Yumnah Șāḥib al-Halwā min al-Asrār, bisa menjadi bukti atau saksi atas kekuatan pengalaman mistik sebagai sumber ilmu pengetahuan. Dalam karya tersebut, Ibn Arabi menceritakan apa yang dia alami selama zikirnya yang intensif. Ternyata melalui zikirnya itu, Ibn Arabi bisa menembus berbagai "dunia", baik dunia fisik maupun non-fisik. Betapa tidak, menurut pengakuannya, dalam zikirnya itu dia dibawa masuk ke dunia mineral dan diperkenalkan pada berbagai batuan permata dan logam-logam dengan segala manfaatnya, baik yang bersifat medis maupun nutritif. Demikian juga ketika terus melanjutkan zikirnya, dia juga masuk ke alam tumbuhan, di mana segala macam tumbuhan memperkenalkan diri mereka beserta manfaat medis dan nutrisinya. Inilah pengalaman mistik yang begitu kaya yang diperoleh lewat hati (intuisi), di mana penelitian akal tidak mengambil andil sedikit pun. ${ }^{48}$

Sedangkan Osman Bakar melaporkan perjalanan sufistik Ibn Sina melalui simbol-simbol material atas semesta hingga tiba pada pencerahan spiritual dalam karyanya Oriental Philosophy. Dalam karya ini, fakta-fakta ilmiah oleh Ibn Sina ditransformasikan dalam simbol-simbol yang berfungsi seperti ramburambu petunjuk bagi para penempuh jalan menuju kesempurnaan spiritual

47Mehdi Gulshani, Filsafat Sains Menurutal-Qur'an, h. 98.

48Mulyadhi Kartanegara, Integrasi Ilmu, h. 113. 
dalam perjalanannya melalui dan melampaui kosmos menuju kehadirat Ilahi. Ibn Sina telah menarik fakta-fakta ilmiah dari berbagai bidang ilmu seperti mineralogi, biologi, astronomi, sosiologi, dan antropologi karena ilmu-ilmu inilah yang dikenal di dunia abad Pertengahan pada masa hidupnya. Realitasrealitas fisik dan astronomis alam semesta yang diuraikan oleh pengetahuan ilmiah tidak lagi dipandang oleh karya ini sebagai objek-objek dan fenomena eksternal untuk dianalisis dan dimanipulasi secara ilmiah. Berkat pengetahuan simbolik tentang alam semesta, Ibn Sina mampu melihat realitas-realitas ini sebagai bagian dari kosmos simbol-simbol yang harus dilalui dalam perjalanan spiritualnya menuju Tuhan. Pengetahuan ilmiah tentang dunia fisik, oleh karena itu, dapat memainkan peran penting dalam perumusan gagasan tentang perjalanan spiritual melalui kosmos dengan syarat bahwa pengetahuan tradisional tentang simbol-simbol itu ada dan diterima. ${ }^{49}$

Sebagian ilmuwan kontemporer telah mengakui eksistensi fakultas intuisi. Alexis Carrel dalam bukunya Man the Unknown mengatakan:

"Jelaslah penemuan-penemuan besar bukanlah produk inteligensia saja. Manusia-manusia genius, sebagai tambahan bagi kekuatan pengamatan dan pemahamannya memiliki kualitas-kualitas lain, seperti intusi dan imajinasi kreatif. Dengan intuisi mereka mempelajari hal-hal yang diabaikan manusia lain; mereka melihat hubungan-hubungan antara fenomena yang nampaknya tidak berhubungan. Semua manusia besar dianugerahi intuisi. Mereka mengetahui apa yang penting mereka ketahui, tanpa analisis dan tanpa penalaran."50

Sedangkan dalam paradigma al-Qur'an, secara umum figur yang telah mengaktualisasikan seluruh fakultas secara holistik; eksperimental, intelektual, dan spiritual adalah ulu al-albāb. Dari beragam deskripsi al-Qur'an, ulu al-albāb memiliki fakultas penalaran, perenungan, ketakwaan, dan pengetahuan. Karakteristik mereka lainnya adalah: mendengarkan kebenaran, mampu menjauhi kepalsuan-kepalsuan, menyembah Tuhan, bijaksana, menyadari, dan mengambil pelajaran dari pengalaman-pengalaman masa lalu. Sehingga kita dapat melihat bahwa ulu al-albāb memiliki hampir seluruh karakteristik di dalam al-Qur'an untuk memahami alam. ${ }^{51}$

\footnotetext{
${ }^{49}$ Osman Bakar, Tauhid dan Sains, h. 156-157. Bandingkan juga dengan Michel Talbot, Mistisisme \& Fisika Baru, terj. Agung Prihantoro, (Yogyakarta: Pustaka Pelajar, 2002).

50Mehdi Gulshani, Filsafat Sains Menurutal-Qur'an, h. 99.

51Mehdi Gulshani, Filsafat Sains Menurutal-Qur'an, h. 103.
} 


\section{Aksiologi Filsafat Sains Untuk Kemanusiaan}

Aksiologi merupakan studi yang menyangkut teori umum tentang nilai atau suatu studi yang menyangkut segala yang bernilai. ${ }^{52}$ Sedangkan menurut Louis O. Kattsoff, aksiologi adalah ilmu pengetahuan yang menyelidiki hakikat nilai, yang umumnya ditinjau dari sudut pandang kefilsafatannya. ${ }^{53}$ Pertanyaan fundamental yang berhubungan dengan aksiologi adalah untuk apa pengetahuan tersebut dipergunakan? ${ }^{54}$ Berhubungan dengan filsafat sains, maka pertanyaan aksiologisnya adalah apa signifikansi filsafat sains Islam bagi kehidupan manusia?

Mari kita lihat aksiologi filsafat sains Islam melalui perspektif Mehdi Golshani. Pertama, jika pengetahuan dari suatu ilmu merupakan persyaratan pencapaian tujuan-tujuan Islam sebagaimana dipandang oleh syariah, maka mencarinya merupakan sebuah kewajiban, karena ia merupakan kondisi awal untuk memenuhi kewajiban syariah. Misalnya, kesehatan badan seseorang di dalam sebuah masyarakat Islam adalah penting. Dari sini, bagi orang-orang Islam, mempelajari ilmu obat-obatan itu wajib kifäyah.

Sebagian orang berpendapat bahwa dalam konteks ini, kewajiban mempelajari suatu ilmu tentu tergantung pada kebutuhan masyarakat pada ilmu itu. Misalnya, pada zaman kita, agar sukses dalam pertanian dengan skala besar atau perdagangan, ilmu khusus tentang masalah ini adalah penting. Dengan demikian, menspesialisasikan bidang-bidang ini bagi orang-orang Islam adalah wajib kifayah. Jelaslah, bahwa kaum Muslim membatasi diri dengan mempelajari apa yang telah ditemukan di negara-negara lain, dengan kata lain, merasa puas dengan sedikit keberhasilan ilmu-ilmu mereka, maka mereka tidak akan pernah mampu memukul dunia non-Muslim dalam hal kemajuan ilmu.

Kedua, masyarakat yang dikehendaki oleh al-Qur'an adalah masyarakat yang agung dan mulia, bukan masyarakat yang takluk dan bergantung kepada orang-orang kafir, seperti bisa kita lihat dalam al-Qur'an di bawah ini:

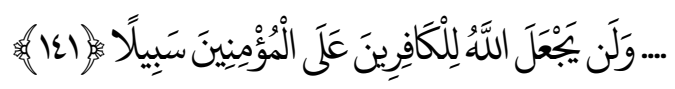

\footnotetext{
${ }^{52}$ Lorens Bagus, Kamus Filsafat, h. 33.

${ }^{53}$ Lois O. Kattsoft, Pengantar Filsafat, h. 319.

${ }^{54}$ Jujun S. Suriasumantri, Filsafat Ilmu Sebuah Pengantar Populer, h. 35.
} 
“... dan Allah sekali-kali tidak akan memberi jalan kepada orang-orang kafir untuk memusnahkan orang-orang beriman." 55

Agar dapat merealisasikan tujuan yang dibahas oleh al-Qur'an ini, masyarakat Islam benar-benar harus memiliki kemerdekaan kultural, politik dan ekonomi. Pada gilirannya, hal ini membutuhkan pelatihan para spesialis kaliber tinggi di dalam segala lapangan dan penciptaan fasilitas-fasilitas ilmiah dan teknik dalam masyarakat Islam. Sungguh jelas bahwa sebab-sebab kemunduran masyarakat kaum Muslim pada abad-abad terakhir ini adalah karena mereka menyerahkan studi ilmu-ilmu tersebut kepada yang lain, padahal mereka sendiri harus lebih mempelajarinya, dan ini membuat mereka sendiri tergantung kepada orang lain.

Di abad modern, kehidupan manusia tidak dapat dipecahkan kecuali dengan upaya pengembangan ilmiah, dan kunci untuk sukses di dalam seluruh urusan bersandar pada ilmu. Karena itu, adalah kewajiban sarjana Muslim dan para peneliti yang tinggal di negara-negara blok Barat atau Timur dan terlibat dalam bidang pendidikan untuk meraih pengetahuan teknik dan ilmiah yang lengkap dan mutakhir. Jika tidak, masyarakat mereka benar-benar akan tetap berada di bawah dominasi satu adikuasa atau yang lain. Imam Ja'far Al-Shadiq berkata: "Seorang yang sadar akan zamannya tidak akan disibukkan oleh masalah-masalah yang tidak diinginkan."

Ringkasnya, jika kaum Muslim ingin sukses perjuangannya dalam melawan kekuatan-kekuatan jahat abad ini, maka mereka harus memperalati dirinya dengan pokok-pokok penting perkembangan keilmuan dan berusaha mengejar kemunduran di dalam lapangan teknik dan keilmuan. Permasalahan apa pun yang penting untuk menjaga eksistensi dan vitalitas masyarakat Islam harus dipelajari.

Ketiga, al-Qur'an menyuruh manusia mempelajari sistem dan skema penciptaan, keajaiban-keajaiban alam, sebab-sebab dan akibat-akibat seluruh benda-benda yang ada, kondisi-kondisi organisme hidup; pendeknya, seluruh tanda-tanda kekuasaan Tuhan yang ada di alam eksternal dan kedalamankedalaman batin jiwa manusia. al-Qur'an menyuruh berpikir dan merenungkan seluruh aspek-aspek penciptaan dan menyuruh manusia menggunakan nalar dan fakultas-fakultas lainnya untuk menemukan rahasia-rahasia alam. Kita bisa melihat seperti QS. Qaf [50]: 6-8:

55QS. al-Nisa'[4]: 141. 


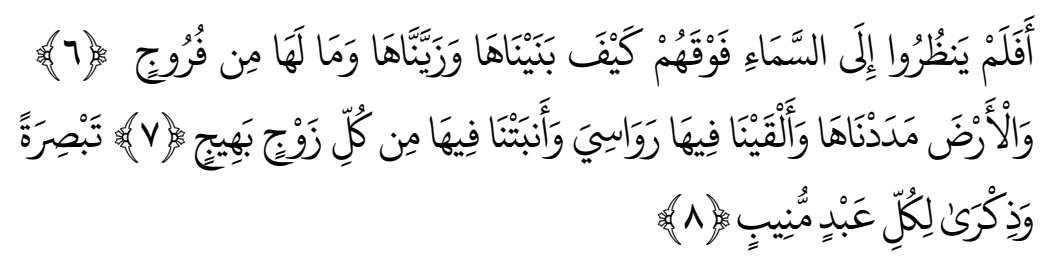

"Maka apakah mereka tidak melihat langit yang ada dia atasnya, bagaimana Kami membangun dan menghiasinya, dan langit itu tidak mempunyai retakretak sedikitpun. Dan Kami hamparkan bumi itu dan Kami letakkan padanya gunung-gunung yang kokoh, dan Kami tumbuhkan padanya segala macam tanaman yang indah dipandang mata, untuk menjadi pelajaran dan peringatan bagi tiap-tiap hamba yang kembali." ${ }^{26}$

Sebagaimana kita lihat dari ayat di atas, Allah menunjukkan seluruh bendabenda yang ada di dalam alam sebagai "tanda-tanda" penciptaanNya, dan sistem alam sebagai rekaman perancang dan Pemrogram yang Mahatahu. Studi tentang alam dan apa-apa yang ada di dalamnya merupakan alat-alat (cara) yang sangat penting untuk mengetahui Allah dan mengenal keagungan pencipta-Nya. 57

Tentunya, sebagaimana disebutkan oleh ayat-ayat tersebut di atas, memahami "tanda-tanda" Pencipta, hanya mungkin bagi orang-orang terdidik dan bijak yang berjuang menggali rahasia-rahasia alam dan yang telah mendapatkan ilmu di dalam bidang-bidang studi mereka. Jika tidak, pengenalan superfisial terhadap "kitab penciptaan" ini saja tidak akan cukup mengungkapkan hal sebenarnya. Suatu awal pemahaman kitab alam yang tepat hanya bisa dicapai lewat ilmu-ilmu semacam matematika, fisika, kimia, astronomi, botani, dan zoologi (ilmu-ilmu kealaman). Dengan pertolongan ilmu-ilmu tersebut dan ilmu-ilmu rasional kita dapat menyimak hukum-hukum alam membuka keajaiban aturan (order) dan skema penciptaan yang mengatur alam. Dalam cahaya inilah seharusnya kita membaca ayat al-Qur'an di bawah ini:

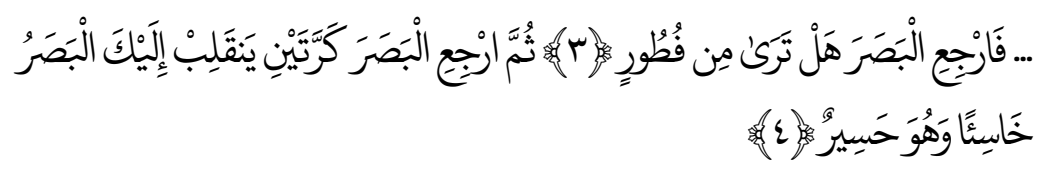

${ }^{56}$ Mehdi Gulshani, Filsafat Sains Menurutal-Qur'an, h. 49-51.

${ }^{57}$ Mehdi Gulshani, Filsafat Sains Menurutal-Qur'an, h. 51. 
"Maka tidaklah berulang-ulang, adakah kamu lihat sesuatu yang tidak seimbang? Kemudian pandanglah sekali lagi dan sekali lagi. Pandanganmu akan kembali pada dirimu, seperti pandangan orang hilang ingatan, letih, dan lesu." 58

Maksud ayat ini adalah bahwa semakin jauh pengetahuan manusia dalam memahami penciptaan Tuhan, maka semakin jelaslah baginya kebesaran dan kemuliaan-Nya. ${ }^{59}$

Keempat, alasan lain untuk mempelajari fenomena-fenomena alam dan skema penciptaan adalah bahwa ilmu tentang hukum-hukum alam dan karakteristik-karakterisitik benda-benda serta organisme-organisme dapat berguna untuk perbaikan kondisi hidup manusia. Masalah ini banyak ditekankan oleh banyak ayat al-Qur'an. ${ }^{60}$ Berikut sebuah ayat yang relevan dengan persoalan ini:

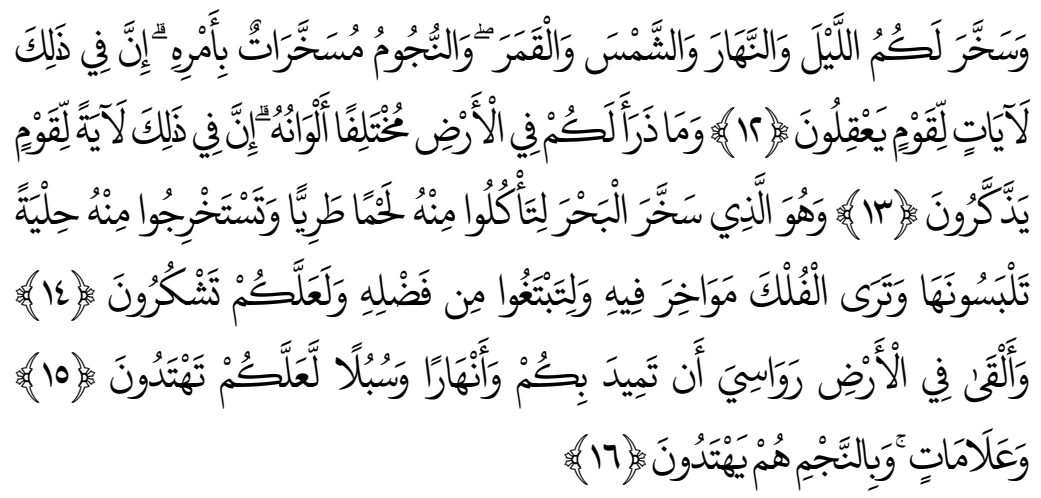

"Dan Dia menundukkan malam dan siang, matahari dan bulan untukmu. Dan binatang-binantang itu ditundukkan (untukmu) dengan perintah-Nya. Sesungguhnya yang pada demikian itu benar-benar ada tanda-tanda (kekuasaan Allah) bagi kaum yang memahami, dan Dia (menundukkan pula) apa yang Dia ciptakan bagi kamu di bumi ini dengan berlain-lainan macamnya. Sesugguhnya pada yang demikian itu benar-benar terdapat tanda-tanda (kekuasaan Allah) bagi kaum yang mengambil pelajaran. Dan Dialah, Allah, yang menundukkan lautan (untukmu), agar kamu dapat memakan darinya daging yang segar (ikan), dan kamu mengeluarkan dari laut itu perhiasan yang kamu pakai; dan kamu melihat bahtera berlayar

${ }^{58} \mathrm{QS}$. al-Mulk [67]: 3-4.

${ }^{59}$ Mehdi Gulshani, Filsafat Sains Menurutal-Qur'an, h. 52-53.

${ }^{60}$ Mehdi Gulshani, Filsafat Sains Menurutal-Qur'an, h. 53. 
padanya, dan supaya kamu mencari (keuntungan) dari karunia-Nya, dan supaya kamu bersyukur. Dan Dia menancapkan gunung-gunung di bumi supaya bumi itu tidak goncang bersama kamu (dan Dia menciptakan) sungai-sungai dan jalan-jalan agar kamu mendapat petunjuk. Dan Dia (menciptakan) tanda-tanda (petunjuk jalan). Dan dengan bintang-bintang itulah mereka mendapat petunjuk." 61

Dalam paradigma al-Qur'an, mempelajari kitab alam semesta akan mengungkapkan rahasia-rahasianya kepada manusia dan menampakkan koherensi (keterpaduan), konsistensi, dan aturan di dalamnya. Ini akan memungkinkan manusia untuk menggunakan ilmunya sebagai perantara untuk menggali kekayaan-kekayaan dan sumber-sumber yang tersembunyi di dalam alam dan mencapai kesejahteraan material lewat penemuan-penemuan ilmiahnya. Tuhan telah menunjukan manusia sebagai wakil dan khalifah-Nya di atas bumi dan diberinya kesempatan-kesempatan yang tidak terbatas. Ia harus mengenal potensi-potensi dirinya, memanfaatkan kesempatan-kesempatan itu, dan memperoleh kekuatan dan kebijaksanaan yang sesuai dengan peranannya sebagai seorang wali Allah dan sebuah "tanda" kebijaksanaan dan kemahatahuan-Nya. ${ }^{62}$

Dalam konteks modern, dimensi aksiologis memahami alam semesta untuk tujuan mengenal Sang Pencipta pun diakui oleh saintis terbesar abad ke20, Albert Einstein. Dalam salah satu risalahnya, Einstein menulis dengan indah:

"I want to know how God created this world. I am not interested in this or that phenomenon, in the spectrum of this or that element, I want to know His thoughts, the rest are details."

Artinya secara bebas kurang lebih: "Aku ingin mengetahui bagaimana Tuhan menciptakan dunia ini. Aku tidak tertarik dengan fenomena ini atau itu, dengan spektrum unsur ini atau itu; Aku ingin mengetahui rancangan-Nya (pikiran Tuhan), sedangkan sisanya hanyalah rincian-rincian saja."63

Lebih jauh, dalam pengamatan (penilikan) E. F. Schumacher ada perbedaan distingtif antara tujuan sains Islam era klasik dengan sains Barat modern setelah renaisans. Meminjam istilah Schumacher, jika sains klasik mempunyai paradigma aksiologis yang berbunyi: science for understanding (sains untuk

\footnotetext{
${ }^{61}$ QS. al-Nahl [16]: 12-16.

62Mehdi Gulshani, Filsafat Sains Menurutal-Qur'an, h. 54.

63Zainal Abidin Bagir (ed.), Science and Religion, h. 94.
} 
pemahaman), maka sains modern mengikrarkan paradigma aksiologis yang berbunyi: science for manipulation (sains untuk manipulasi). ${ }^{64}$ Sains demi pemahaman mempunyai tujuan utama kepada kebajikan tertinggi yaitu yang Benar, yang Baik, dan yang Indah; sebuah pengetahuan yang akan membawa kepada kebahagiaan dan keselamatan umat manusia. Sebab sains klasik memandang alam semesta sebagai hasil karya Tuhan (God's handwork), sementara sains untuk manipulasi hanya bertujuan untuk meraih penguasaan material semata. 65

Pada level inilah, sebagian ilmuwan Muslim menganggap alam semesta pun sebagai sesuatu yang sakral sebab ia berasal dari Tuhan yang Mahasuci dan pemahaman terhadap alam semesta bertujuan untuk mengenal dan mendekat kepada Yang Mahasuci tersebut demi kebahagiaan manusia itu sendiri. Karena sains Islam berpijak pada pandangan tawhïd, memandang Tuhan sebagai Pencipta dan Pemelihara alam semesta, maka tidak berlebihan jika Golshani menamakan sains Islam sebagai sains sakral atau sacred science, yang berbeda dengan sains sekuler atau secular science.

Orientasi pengabdian pada Sang Pencipta yang harus berujung kepada kebahagiaan manusia dapat disimak dari perbedaan antara sains sakral dan sains sekuler yang dieksplorasi oleh Golshani. Pertama, sains sekular menganggap dunia fisik sebagaimana adanya dan melihat tidak ada ruang bagi Tuhan dalam tatanan alam semesta. Sedangkan sains sakral justru memandang alam semesta diciptakan dan dipelihara oleh Tuhan yang Maha Mengetahui lagi Mahakuasa. Sehingga, sains sakral berpusat pada Tuhan-God centered.

Kedua, sains sekuler berisi spesialisasi/pemisahan dan menjadikan fragmentasi ilmu. Setiap ilmu mempunyai wilayah yang terpisah masing-masing dan tercerabut dari dimensi sakral. Sedangkan sains sakral justru berupaya menyibak kesatuan yang mendasari tatanan semesta. Dengan kata lain, sains sakral mempunyai pandangan holistik kepada alam semesta dan menerapkan sebuah pendekatan holistik pula. Sehingga tidak ada dikotomi ilmu ke dalam kategori agama dan sekuler. Jenis ilmu apa pun yang bertujuan memenuhi citacita Islam untuk kemajuan, kesejahteraan, dan kebahagiaan manusia, maka dianggap sakral.

64Zainal Abidin Bagir (ed.), Science and Religion, h. 97.

${ }^{65}$ Zainal Abidin Bagir (ed.), Science and Religion, h. 97. 
Ketiga, sains sekuler hanya menganggap kajiannya pada wilayah fisikal, sehingga realitas spiritual dianggap tidak ada. Bagi sains sekuler tidak ada ruang bagi supra-material (ghayb). Sudut pandang inilah yang disebut saintisme: perspektif yang memandang bahwa sainslah satu-satunya jalan menuju kebenaran. ${ }^{66}$ Sementara sains sakral mengakui bahwa disamping ada wilayah material, ada pula wilayah spiritual yang harus didekati dengan wahyu dan intuisi. Sains sakral mengikrarkan diri bahwa terdapat dimensi kenyataan yang lebih luas daripada yang bisa dilihat oleh mata manusia.

Keempat, sains sekuler mengabaikan/menolak gagasan mengenai tujuan alam semesta. Sedangkan sains sakral memandang alam semesta mempunyai sebuah makna yang melampaui kehidupan kita dan berhubungan dengan tujuan eksistensinya. Sehingga kehidupan yang penuh makna, adalah untuk mengabdi kepada Tuhan dalam segala aspek kehidupan. Kelima, sains sekuler mempromosikan netralitas nilai, sedangkan sains sakral menggabungkan ilmu dengan nilai. Artinya, sains sekuler menafikan nilai moral sedangkan sains sakral justru menjadikan prinsip moral sebagai bagian sains.

Keenam, dalam konteks sekularistik, sains bertujuan untuk mengontrol dan memanipulasi alam semesta dan masyarakat. Sedangkan dalam konteks ketuhanan, sains bertujuan untuk memperoleh kearifan dan untuk menangani problem-problem individual dan sosial kemanusiaan dengan prinsip meraih ridha Tuhan.

Ketujuh, karena keterbatasan wilayahnya, sains sekuler hanya mampu merespon pertanyaan-pertanyaan spesifik dan tidak mampu melukiskan sebuah gambaran dunia yang komprehensif. Sains sekuler tidak berbicara sedikitpun tentang kebaikan dan keburukan, kebahagiaan dan kesengsaraan, Tuhan dan keabadian, tentang makna dan moralitas. Sedangkan sains sakral, karena mencakup wilayah yang komprehensif, maka ia juga berbicara tentang problem-problem abadi kehidupan umat manusia. ${ }^{67}$

Dengan demikian, dimensi aksiologis sains dalam paradigma Islam adalah demi kebahagiaan umat manusia dalam segala aspeknya sekaligus untuk memahami dan mendekati Sang Pencipta sekaligus membawa manfaat demi

66Tentang saintisme lihat Louis Leahy, Aliran-aliran Besar Ateisme (Yogyakarta: Kanisius, 1985), h. 138-140. Bandingkan dengan Huston Smith, Why Religion Matters (New York: HarperCollins Publishers, 2001), h. 59-78.

67Zainal Abidin Bagir (ed.), Science and Religion, h. 98-102. 
kebahagiaan umat manusia dalam segala aspeknya. Sehingga aksiologis sains Islam mengikrarkan sebuah prinsip bahwa dimensi profanitas alam semesta tidak dapat dipisahkan dari dimensi sakralitas tujuannya dalam mengabdi kepada Tuhan Sang Pencipta dan berujung pada kemajuan, kesejahteraan, kebaikan, dan kebahagiaan manusia. Melalui kajian aksiologis inilah, filsafat sains tidak akan pernah kehilangan spirit signifikansi dan aktualitasnya dalam mengemban misi kemanusiaan dalam bingkai pengabdian kepada Sang Pencipta.68

\section{E. Kesimpulan}

Dari berbagai eksposisi di atas kita melihat bahwa semangat eksperimentasi dalam perspektif Islam tidak menyebabkan munculnya empirisme, materialisme, dan naturalisme. Sebab, walaupun Islam memandang penting dimensi eksperimentasi, namun pengalaman indrawi bukan satu-satunya sumber pengetahuan. Demikian pula, meskipun penggunaan rasio sangat diapresiasi dalam Islam untuk menelaah alam semesta, tapi tidak sampai menyebabkan tumbuhnya rasionalisme. Lagi-lagi semua ini disebabkan aplikasi eksperimentasi dan nalar dalam membaca wajah alam semesta tidak pernah terlepas dari spirit keimanan kepada Sang Pencipta. Para ilmuwan Muslim selalu diilhami oleh kesadaran religius yang kuat terhadap Tuhan, sebagai sumber segalanya. ${ }^{69}$

Kendati demikian, kita tidak boleh menutup mata bahwa semangat saintifik dalam dunia Islam masih cukup lemah, bahkan sampai memasuki milenium ketiga ini. karenanya ada kebutuhan yang cukup urgen untuk menghidupkan kembali spirit saintifik yang bersifat integral-holistik dalam diri umat Islam secara global. Akhirnya saya tidak mampu menawarkan solusi konstruktif-argumentatif sebagaimana solusi kreatif yang disuguhkan filosof sains Islam kontemporer asal Iran, Mehdi Golshani. ${ }^{70}$

Dalam kontek ini, menurut Mehdi kita bisa mempertimbangkan beberapa solusi berikut: Pertama, seperti ulama dan ilmuwan abad-abad pertama zaman Islam, kita harus mempelajari seluruh ilmu yang berguna dari orang-orang lain.

\footnotetext{
68Untuk menyimak wacana sains sakral secara cukup holistik, lihat dalam Seyyed Hossein Nasr, The Need for a Sacred Science, (The United Kingdom: Curzon Press, 1993).

${ }^{69}$ Osman Bakar, Tauhid dan Sains, h. 71-77.

${ }^{70}$ Mehdi Gulshani, Filsafat Sains Menurutal-Qur'an, h. 72.-73.
} 
Kita dapat membebaskan pengetahuan ilmiah dari penafsiran-penafsiran materialistik Barat dan mengembalikannya ke dalam konteks pandangan dunia dan ideologi Islam. ${ }^{71}$ Para ulama Islam dulu melakukan hal yang sama dan apa yang harus kita lakukan kini adalah menerima ilmu dari orang-orang nonMuslim dengan cara yang selektif. Yaitu dengan membersihkannya dari unsurunsur yang menyimpang dari Islam dan membentuk kembali ilmu itu dengan cahaya pandangan Islam. Dengan petunjuk prinsip-prinsip inilah kaum Muslim dapat meraih ilmu dari sumber-sumber non-Muslim dan membentuknya sesuai dengan cita-cita Islam. Hanya di bawah kondisi-kondisi inilah tingkatantingkatan ilmu yang berbeda dapat dikoordinasikan untuk meraih tujuan kita dan dapat membawa kita lebih dekat kepada Allah. ${ }^{72}$

Kedua, bentuk gabungan yang ada di antara ilmu-ilmu agama dan ilmuilmu kealaman selama hari-hari puncak Islam harus dibangun kembali, karena sebagaimana telah ditunjukkan, bahwa antara titik-akhir agama dan ilmu-ilmu kealaman tidak ada konflik. Ilmu pengetahuan juga berguna dalam usaha menyingkap suatu kesatuan komprehensif di dalam hukum-hukum alam. Sekarang para ahli fisika terlibat di dalam upaya mereduksi seluruh kekuatan alam yang tampaknya saling tidak tergantung kepada suatu kekuatan fundamental tunggal. Mereka telah meraih beberapa keberhasilan di dalam bidang ini. Untuk mencapai tujuan ini, tampaknya tidak dapat dielakkan bahwa prinsip-prinsip ilmiah mutakhir harus diajarkan di universitas-universitas pada tahap lajut yang dikembangkan dengan sebanding. Ini akan menjadi alat dalam mengakrabkan penyelidikan para sarjana peneliti Muslim dengan pandangan Islam. Lebih dari itu, ia akan memberikan kesempatan kepada sekolah-sekolah teologi untuk menggunakan penemuan-penemuan ilmiah dalam menerangkan isi hukum syariah.

Ketiga, untuk mencapai kemerdekaan penuh umat Islam, negara-negara Muslim perlu mengambil langkah-langkah untuk melatih para spesialis di dalam segala bidang keilmuan dan industri yang penting. Lebih dari itu, pusatpusat riset harus didirikan oleh seluruh komunitas Muslim, sehingga para peneliti Muslim dapat bekerja tanpa dibarengi kecemasan, dan dengan menggunakan segala fasilitas yang perlu untuk dilakukan riset. Sehingga

\footnotetext{
${ }^{71}$ Mehdi Gulshani, Filsafat Sains Menurut al-Qur'an, h. 60.

72 Mehdi Gulshani, Filsafat Sains Menurutal-Qur'an, h. 73.
} 
mereka tidak terpaksa harus berlindung dalam lingkungan ateistik, dan sebagai akibatnya terpaksa menerapkan keahlian mereka untuk membantu orang lain, bukan masyarakatnya sendiri.

Keempat, penyelidikan ilmiah harus dipikirkan sebagai sebuah pencarian penting dan mendasar, dan bukanlah pencarian yang sekedarnya. Orang-orang Islam harus memikirkannya sebagai sebuah kewajiban yang dipaksakan kepada mereka oleh al-Qur'an, sehingga mereka tidak tergantung pada orang lain. Sekarang, praktis di seluruh negara Muslim adalah mengimpor seluruh mesin dengan sedikit pengetahuan assembling dari negara-negara Timur dan Barat daripada melakukan usaha serius dalam riset ilmiah yang fundamental. Kecondongan sekarang tidak akan mengarahkan negara-negara Islam pada kemandirian diri dalam masalah teknologi dan keilmuan. Mengimpor teknologi harus disertai dengan kerja riset yang asli (indigenous).

Kelima, harus ada kerja sama antara negara Muslim dalam masalah riset tekonologi dan keilmuan. Untuk tujuan ini, penciptaan jaringan komunikasi di antara universitas mereka dapat dijadikan permulaan. Lebih dari itu, kerja sama badan-badan penelitian dan pengembangan harus dibentuk oleh negaranegara Muslim di mana para ilmuwan dan sarjana peneliti Muslim dapat bekerjasama. Dalam hal ini tidak boleh ada bias nasionalistik. Pusat-pusat semacam itu banyak terdapat pada masa peradaban Islam abad silam. Semua yang dikerjakan selama ini, dalam kaitannya dengan masalah tersebut, sama sekali belum sempurna. Kinilah saatnya yang tepat untuk membuat langkah menentukan pada arah ini.73

Terakhir, al-Qur'an menyebutkan para pengikut Islam sebagai umat yang mempunyai keseimbangan dengan adil antara dimensi material dan spiritual dalam kehidupan. ${ }^{74}$ Dengan demikian orang-orang Islam tidak boleh, seperti orang-orang Barat, terlibat terlalu dalam pada aspek kehidupan material dan tidak boleh melupakan dimensi eksistensi spiritual. Orang-orang Islam harus sadar akan fakta bahwa dalam perspektif Islam, seluruh keuntungankeuntungan material itu diizinkan, tetapi bukan sebagai akhir dalam keuntungan-keuntungan material itu sendiri. Ia bertindak sebagai tangga bagi kemajuan spiritual manusia.

${ }^{73}$ Mehdi Gulshani, Filsafat Sains Menurut al-Qur'an, h. 60-61.

${ }^{74}$ Lihat dalam QS. al-Baqarah [2]: 143 \& 201, \& QS. (28): 77. 
Ringkasnya, sekarang kita menghadapi dua realitas. Pada satu sisi kita melihat Barat telah maju dalam berbagai lapangan sains dan teknologi yang mengagumkan, dan sisi lain, kemajuan material ini tidak membawa kepuasan kepada manusia Barat. Ia sesungguhnya telah menenggelamkan dirinya ke dalam lubang perangkap nihilisme; Dalam keadaan semacam ini, kewajiban kaum Muslim adalah mengisi ketimpangan-ketimpangan mereka dalam lapangan sains dan teknologi, dan, dengan membangkitkan kembali ajaranajaran Islam dan pandangan Islam yang luhur, mereka dapat membimbing kemanusiaan ke arah kesejahteraan dan kebahagiaan sejati. ${ }^{75}[\mathrm{w}]$

75Mehdi Gulhani, Filsafat Sains Menurut al-Qur'an, h. 76-77. 


\section{BIBLIOGRAPHY}

Bagir, Zainal Abidin (ed.), Science and Religion, Australia: ATF Press, 2005.

Bagus, Lorens, Kamus Filsafat (Dictionary of Philosophy), Jakarta: Gramedia Pustaka Utama, 2002.

Bakar, Osman, Tauhid dan Sains (Tauhid and Science), translated by Yuliani Liputo \& M.S. Nasrulloh, Bandung: Pustaka Hidayah, 2008.

al-Ghazali, Syaikh Muhammad, Berdialog dengan al-Qur'an (Dialogue with Quran), translated by Masykur Hakim dan Ubaidillah, Bandung: Mizan, 1997.

Gulshani, Mehdi, Filsafat Sains Menurut al-Qur'an (Philosophy of Science According to Quran), translated by Agus Effendi, Bandung: Mizan, 1989.

Gulshani, Mehdi, Melacak Jejak Tuhan dalam Sains (Tracking the Step of God in Science), translated by Ahsin Muhammad, Bandung: Mizan, 2004.

Heriyanto, Husein, Menggali Nalar Saintifik Peradaban Islam (Digging Up the Scientific Logic of Islamic Civilzation), Bandung: Mizan, 2011.

Kartanegara, Mulyadhi, Pengantar Epistemologi Islam (Introduction to Islamic Epistemology), Bandung: Mizan, 2003.

Kartanegara, Mulyadhi, Integrasi Ilmu (Integration of Science), Jakarta: UIN Jakarta Press, 2005.

Kattsoft, Lois 0, Pengantar Filsafat (Introduction to Philosophy), Yogyakarta: Tiara Wacana, 2004.

Leahy, Louis, Aliran-Aliran Besar Ateisme (The Main Schools of Atheism), Yogyakarta: Kanisius, 1985.

Nakosteen, Mehdi, Kontribusi Islam atas Dunia Intelektual Barat (Contribution of Islam to Western Intellectual World), translated by Joko S. Kahhar \& Supriyanto Abdullah, Surabaya: Risalah Gusti, 2003.

Nasr, Seyyed Hossein, The Need for a Sacred Science, The United Kingdom: Curzon Press, 1993.

Nasr, Seyyed Hossein, Science and Civilization in Islam, New York: A Plume Book, 1970.

Walisongo, Volume 23, Nomor 2, November 2015 
Palmquis, Stephen, Pohon Filsafat (The Tree of Philosophy), translated by Muhammad Shodiq, Yogyakarta: Pustaka Pelajar, 2007.

Purwanto, Agus, Ayat-ayat Semesta (The Verses of Universe), Bandung: Mizan, 2009.

Smith, Huston, Why Religion Matters, New York: Harper Collins Publishers, 2001.

Suriasumantri, Jujun S, Filsafat Ilmu Sebuah Pengantar Populer (Philosophy of Science: a Popular Introduction), Jakarta: Pustaka Sinar Harapan, 1996.

Shihab, M. Quraish al-Qur'an dan Maknanya (al-Quran and Its Meaning), Tangerang: Lentera hati, 2010.

Syamsuddin, Ach. Maimun, Agama dan Sains (Religion and Science), Yogyakarta: IRCiSoD, 2012.

Talbot, Michel, Mistisisme \& Fisika Baru (Mysticism and New Physics), translated by Agung Prihantoro, Yogyakarta: Pustaka Pelajar, 2002.

Yahya, Harun, Pustaka Sains Populer Islami (Library of Islamic Popular Science), translated by Catur Sriherwanto, Bandung: Sygma Publishing, 2011. 